\title{
Retrospective evaluation of vector-borne infections in dogs imported from the Mediterranean region and southeastern Europe (2007-2015)
}

Ingo Schäfer ${ }^{1 *}$, Maria Volkmann², Pamela Beelitz ${ }^{3}$, Roswitha Merle², Elisabeth Müller ${ }^{4}$ and Barbara Kohn ${ }^{1}$

\begin{abstract}
Background: Canine vector-borne infections have gained importance in Germany due to growing tourist traffic and an increased import of dogs from abroad. Endemic regions for pathogens such as Leishmania infantum, Hepatozoon canis, Ehrlichia canis, Anaplasma platys and Dirofilaria spp. are the Mediterranean area and southeastern Europe. Babesia species and Anaplasma phagocytophilum are present all over Europe. The objective of this retrospective study was to evaluate the prevalence of vector-borne infections in dogs imported from defined endemic countries in the Mediterranean area and southeastern Europe.

Methods: Medical records and laboratory test results of 345 dogs that were imported to Germany from 17 endemic countries and that were presented to the Small Animal Clinic at Freie Universität Berlin between 2007 and 2015 were retrospectively reviewed. A total of 1368 test results from external laboratories were descriptively analysed including 576 and 792 test results of direct and indirect detection methods, respectively.

Results: Overall, 35\% (122/345 dogs) were positive for at least one pathogen. Concurrent infections with two to four pathogens were detected in 8\% of the dogs (27/345). The positive results were: L. infantum 21\% (66/314 dogs; methods: PCR 20/79, IFAT or ELISA 63/308 dogs), E. canis 16\% (45/278 dogs; methods: PCR 8/68, IFAT 43/257 dogs), H. canis 11\% (3/28 dogs; method: PCR), Babesia spp. 10\% (25/251 dogs; methods: Babesia spp. PCR 3/98, B. canis/ vogeli IFAT or ELISA 22/214 and B. gibsoni IFAT 0/13 dogs), Dirofilaria spp. 7\% (13/178 dogs; methods: D. immitis Ag-ELISA 8/156, Knott's test 7/95, microfilariae PCR 5/23 dogs) and A. platys 5\% (1/21 dogs; method: PCR). None of 8 tested dogs were positive in a combined Babesia spp./Hepatozoon spp. PCR test.

Conclusions: Dogs, which are imported from countries which are endemic for vector-borne infections should be thoroughly tested using direct and indirect detection methods. Potential owners of imported dogs should be informed about the diseases, risks and incubation periods.
\end{abstract}

Keywords: Arthropod-transmitted infections, Vector-borne diseases, Laboratory diagnostics, Import

\footnotetext{
* Correspondence: ingo.schaefer@fu-berlin.de

${ }^{1}$ Clinic for Small Animals, Faculty of Veterinary Medicine, Freie Universität

Berlin, Berlin, Germany

Full list of author information is available at the end of the article
}

(c) The Author(s). 2019 Open Access This article is distributed under the terms of the Creative Commons Attribution 4.0 International License (http://creativecommons.org/licenses/by/4.0/), which permits unrestricted use, distribution, and reproduction in any medium, provided you give appropriate credit to the original author(s) and the source, provide a link to the Creative Commons license, and indicate if changes were made. The Creative Commons Public Domain Dedication waiver (http://creativecommons.org/publicdomain/zero/1.0/) applies to the data made available in this article, unless otherwise stated. 


\section{Background}

Blood-feeding arthropods transmit parasitical, bacterial or viral pathogens, which can result in infections in a host. With respect to long incubation times in the case of some infections and the wide range of unspecific clinical signs, especially for dogs with multiple infections, diagnosis and therapy might be difficult [1-4]. The occurrence of these so-called vector-borne infections depends on the geographical existence of the vectors and reservoirs [5]. The import of infected dogs has several effects in non-endemic countries. Pathogens can be imported to non-endemic countries via infected dogs. Non-endemic vectors can be imported and gain vector competence. Endemic vectors can be infected with non-endemic pathogens and may serve as alternate competent vectors by blood-feeding on a naive dog. Due to the import of infected dogs and climatic changes in Europe, vectors have the potential to infest non-endemic environments in more northern countries such as Germany and spread pathogens in accordance with the vectors' competence $[1,6]$. Areas in Europe endemic for pathogens such as Leishmania spp., Hepatozoon canis, Ehrlichia canis, Anaplasma platys and Dirofilaria immitis are the Mediterranean region and southeastern Europe. Meanwhile Anaplasma phagocytophilum and Babesia spp. are endemic in Germany [7]. B. canis has been ascertained sporadically in certain regions in Germany [8-12], including the area Berlin-Brandenburg [13]. Two cases of autochthonous infections with B. gibsoni have been previously described in Germany [14] and occasional autochthonous Dirofilaria repens infections in Germany have been detected [15-17].

Dogs in endemic countries are at high risk of vectorborne infections. Only a few studies have described test results for vector-borne infections in dogs imported from endemic countries to Germany [18-23]. Therefore, the objective of the present study was to evaluate the prevalence of vector-borne infections in a population of dogs that were imported from endemic regions in the Mediterranean area and southeastern Europe, and that were presented to the Small Animal Clinic at Freie Universität (FU) Berlin, Germany.

\section{Methods}

This study was performed retrospectively. The dogs were presented to the Small Animal Clinic at FU Berlin between January 2007 and December 2015 and were identified by keyword search in the clinic's software program and enquiries to external laboratories (Laboklin, Bad Kissingen; Institute for Experimental Parasitology, LudwigMaximillians-University, Munich). Only dogs with an origin from a defined endemic country (13 Mediterranean countries and 4 countries in southeastern Europe) and at least one direct or indirect examination for vector-borne infections were included in the study (Tables 1 and 2).
Direct testing methods included PCR, Ag-ELISA and Knott's test. Indirect testing methods included IFAT and Ab-ELISA (Table 1). Descriptive statistical analysis was ascertained via SPSS for Windows (version 24.0, SPSS Inc., Armonk, NY, USA). Chi-square test was used to compare categorical variables and results are given as percentages. Statistical significance was set at $P<0.05$.

\section{Results}

\section{Signalment/history}

In total 345 dogs were imported from 16 endemic countries (Table 2); no dogs were brought to Germany from Serbia. Most dogs originated from Spain (186/345, 54\%), Greece (48/345, 14\%), Italy (19/345, 6\%), Hungary (19/345, 6\%) and Portugal $(12 / 345,3 \%)$. Information on sex and breed was available for 344 dogs: 179 (52\%) were females and 165 (48\%) were males; 202 (65\%) were mixed breed and 122 (35\%) were purebred dogs, belonging to 59 different breeds. The age was known in 335 dogs, with a median of $4.7(0.2-16.1)$ years. A total of $287 / 345$ cases (83\%) were presented with clinical signs and the remainder without clinical signs were presented for routine medical check-up. The time between import to Germany and presentation in the clinic is depicted in Table 3. Clinical signs were present in 41/50 dogs (82\%) living in Germany for 0-2 months, 28/33 (85\%) living in Germany for 2-6 months, 40/44 (91\%) living in Germany for 6-12 months, $81 / 98$ (83\%) living in Germany for $1-5$ years, $16 / 18$ (89\%) living in Germany for 5-7 years and 24/35 (69\%) living in Germany for longer than 7 years.

\section{Laboratory diagnostics}

In total, 1368 tests for vector-borne infections were initiated between January 2007 and December 2015. Thereof $55 / 576$ direct (10\%) and 128/792 indirect tests (16\%) were positive (Table 4). Twenty-five of 251 dogs (10\%) were positive for Babesia spp.: in two of these dogs, $B$. canis was identified after species differentiation using PCR; in one dog (PCR positive) and in 22 serologically positive dogs, species differentiation was not performed. Thirteen of 178 dogs (7\%) were positive for microfilariae. In eight of 13 dogs $D$. immitis, three of 13 dogs $D$. repens and one of 13 dogs, Acanthocheilonema reconditum was detected. In one case further microfilarial differentiation was not performed.

Twenty-seven of 345 dogs (8\%) were infected with two to four pathogens. In 24/345 dogs two pathogens were detected: nine dogs with Babesia spp. and L. infantum (seven dogs from Spain, two dogs from Malta), six dogs with $E$. canis and L. infantum (three dogs from Spain, two dogs from Greece, one dog from Malta), four dogs with $E$. canis and Babesia spp. (two dogs from Greece, one dog each from Italy and Cypress) and in one dog each the following co-infections were detected: $L$. infantum $+D$. repens (Spain); 
Table 1 Direct and indirect methods of detection for vector-borne infections initiated in imported dogs

\begin{tabular}{|c|c|c|c|}
\hline Infectious agent & Test & LMU Munich & Laboklin \\
\hline \multirow[t]{2}{*}{ Ehrlichia canis } & PCR & Applied Biosystems TaqMan@ Real Time PCR [71] & TaqMan@ Real Time PCR (in-house test) \\
\hline & Ab-IFAT & $\begin{array}{l}\text { MegaScreen@ FLUOEHRLICHIA canis } \\
\text { (MegaCor Diagnostik GmbH, Hörbranz, } \\
\text { Austria; } \geq 1: 40 \text { positive) }\end{array}$ & $\begin{array}{l}\text { MegaFLUO@ EHRLICHIA canis } \\
\text { (MegaCor Diagnostik GmbH, Hörbranz, } \\
\text { Austria; } \geq 1: 80 \text { positive) }\end{array}$ \\
\hline Anaplasma platys & PCR & Applied Biosystems TaqMan@ Real Time PCR [72] ${ }^{a}$ & TaqMan@ Real Time PCR (in-house test) \\
\hline \multirow[t]{3}{*}{ Leishmania infantum } & PCR & Applied Biosystems TaqMan@ Real Time PCR [73] & TaqMan® Real Time PCR [74] \\
\hline & Ab-IFAT & Leishmania infantum MON-1 [75]; $\geq 1: 64$ positive & $\begin{array}{l}\text { MegaFLUO@ LEISH (MegaCor Diagnostik } \\
\text { GmbH, Hörbranz, Austria; > 1:64 positive) }\end{array}$ \\
\hline & Ab-ELISA & - & $\begin{array}{l}\text { Civtest } \odot \text { Canis Leishmania (Hipra, Amer, } \\
\text { Spain; > 1,1 LE positive) }\end{array}$ \\
\hline Babesia spp. & $P C R^{b}$ & PCR (18S rRNA) with gel electrophoresis [76 ${ }^{c}$ & PCR (18S rRNA) with gel electrophoresis [77] ${ }^{d}$ \\
\hline \multirow[t]{2}{*}{ Babesia canis ${ }^{\mathrm{e}}$} & Ab-IFAT & $\begin{array}{l}\text { MegaScreen@ FLUOBABESIA canis (MegaCor } \\
\text { GmbH, Hörbranz, Austria; } \geq 1: 64 \text { positive) }\end{array}$ & $\begin{array}{l}\text { MegaFLUO@ BABESIA canis (MegaCor } \\
\text { GmbH, Hörbranz, Austria; } \geq 1: 40 \text { positive) }\end{array}$ \\
\hline & Ab-ELISA & - & $\begin{array}{l}\text { Babesia ELISA Dog (Afosa, Blankenfelde-Mahlow, } \\
\text { Germany; } 19 \text { TE positive) }\end{array}$ \\
\hline Babesia gibsoni & Ab-IFAT & $\begin{array}{l}\text { MegaScreen@ FLUOBABESIA gibsoni-Testkit } \\
\text { (MegaCor GmbH, Hörbranz, Austria; } \geq 1: 64 \text { positive) }\end{array}$ & $\begin{array}{l}\text { MegaFLUO@ BABESIA gibsoni (MegaCor } \\
\text { GmbH, Hörbranz, Austria; } \geq 1: 32 \text { positive) }\end{array}$ \\
\hline Babesia spp./Hepatozoon spp. & $P C R^{b}$ & In-house protocol & - \\
\hline Hepatozoon canis & PCR & PCR (18S rRNA) with gel electrophoresis $[78]^{f}$ & TaqMan@ Real Time PCR (in-house test) \\
\hline Dirofilaria spp. & Knott's test & Modified Knott's test [79] & Modified Knott's test [79] \\
\hline Microfilariae & PCR & PCR (IST-2) with gel electrophoresis [80] ${ }^{c}$ & TaqMan@ Real Time PCR (in-house test) ${ }^{f}$ \\
\hline Dirofilaria immitis & $\mathrm{Ag}$-ELISA & $\begin{array}{l}\text { Dirochek@ Canine Heartworm Antigen Test Kit } \\
\text { (Synbiotics Corporation, San Diego, California } \\
\text { 92127, US Veterinary License No. 312; Megacor) }\end{array}$ & $\begin{array}{l}\text { FASTest@ HW Antigen (MegaCor GmbH, } \\
\text { Hörbranz, Austria) }\end{array}$ \\
\hline $\begin{array}{l}\text { an combination with A. phagocy } \\
\text { bDifferentiation between differen } \\
\text { "Species differentiation after seq } \\
\text { "Sequencing of the PCR-product } \\
\text { 'S Serological cross-reactions betw } \\
\text { f } 18 \text { rRNA, 2012-2015 (2007-201 } \\
\text { Abbreviations: LMU Munich, Instit } \\
\text { PCR, polymerase chain reaction; } \\
\text { linked immunosorbant assay }\end{array}$ & $\begin{array}{l}\text { philum PCR du } \\
\text { species possib } \\
\text { encing of the } P \\
\text { y request of th } \\
\text { en B. canis und } \\
\text { no data availa } \\
\text { te for Experim } \\
\text { g-ELISA, antige }\end{array}$ & $\begin{array}{l}\text { to sequence homology } \\
\text { e by request of veterinarian } \\
\text { CR product and comparison with the database GenBank (N } \\
\text { e veterinarian } \\
\text { B. vogeli possible } \\
\text { le) } \\
\text { ntal Parasitology, Ludwig-Maximilians-University Munich, G } \\
\text { enzyme-linked immunosorbant assay; Ab-IFAT, immunofl }\end{array}$ & $\begin{array}{l}\text { ermany; Laboklin, Laboklin, Bad Kissingen, Germany; } \\
\text { orescence antibody test; Ab-ELISA, antibody enzyme- }\end{array}$ \\
\hline
\end{tabular}

L. infantum and positive Knott's test (Dirofilaria spp. not differentiated, Spain); E. canis + Acanthocheilonema reconditum (Spain); L. infantum + D. immitis (Spain); and $E$. canis $+H$. canis (Cypress). Two dogs imported from Greece were positive for three pathogens, in one E. canis + Babesia spp. + D. repens and in the other Babesia spp. + L. infantum + D. immitis. In one dog from Spain the following four pathogens were detected: $E$. canis, Babesia spp., L. infantum and D. immitis.

The number of dogs tested for vector-borne infections was the highest in the period 2013-2015 compared to the periods 2007-2009 and 2010-2012 (Fig. 1). Tests using a combined PCR for Babesia spp./Hepatozoon spp. were only initiated in the year 2008. The number of dogs with positive test results for vector-borne infections (Fig. 1) was not significantly different between the three time periods (2007-2009, 2010-2012, 2013-2015), neither for total analyses $\left(\chi^{2}=0.925 ; d f=2 ; P=0.630\right)$ nor for $E$. canis $\left(\chi^{2}=0.107 ; d f=2 ; P=0.948\right)$, L. infantum $\left(\chi^{2}=0.144 ; d f=\right.$ 2; $P=0.931)$, Babesia spp. $\left(\chi^{2}=1.954 ; d f=2 ; P=0.376\right)$ and Dirofilaria spp. $\left(\chi^{2}=3.953 ; d f=2 ; P=0.139\right)$. No statistical analysis was performed for $A$. platys and $H$. canis because a minimum of ten dogs should be tested for every pathogen in every period. In proportion to the total number of dogs presented in the clinic between 2007 and 2015 the percentage of dogs tested for vector-borne infections was 1\% (345/33925 dogs). In 2007 the proportion was the highest with $1.2 \%(37 / 3110$ dogs $)$. In the periods 2008-2009 and 2011-2015 the proportion ranged between 0.6 and $0.9 \%$. The proportion was lowest in the year 2010 with $0.4 \%$ (28/6537 dogs).

\section{Discussion}

In $35 \%$ of 345 imported dogs tested for vector-borne infections, at least one pathogen was detected. The most common pathogen was L. infantum with $21 \%$ of tested dogs being positive, followed by $E$. canis with $16 \%$. Eleven percent of dogs were positive for $H$. canis and $10 \%$ for Babesia spp. Anaplasma platys was detected in $5 \%$ of tested dogs. Eight percent of dogs were positive 
Table 2 Number of vector-borne infections in dogs import from endemic countries (number of monoinfections/number of multiple infections)

\begin{tabular}{|c|c|c|c|c|c|c|c|c|c|c|c|}
\hline Country of origin & No. of dogs tested positive/total (\%) & E. can & A. pla & L. inf & B. $\mathrm{spp}^{\mathrm{a}}$ & B. $\mathrm{can}^{\mathrm{b}}$ & H. can & D. $\operatorname{spp}^{c}$ & D. imm & D. rep & Ac. rec \\
\hline Spain & $67 / 186(36)$ & $10 / 6$ & $1 /-$ & $35 / 14$ & $-/-$ & $4 / 8$ & $-1-$ & $-/ 1$ & $2 / 2$ & $-/ 1$ & $-/ 1$ \\
\hline Greece & $22 / 48(46)$ & $8 / 5$ & $-/-$ & $7 / 3$ & $-/-$ & $-/ 4$ & $-/-$ & $-1-$ & $1 / 1$ & $-/ 1$ & $-/-$ \\
\hline Hungary & $4 / 19(21)$ & $-1-$ & $-/-$ & $-/-$ & $1 /-$ & $1 /-$ & $-1-$ & $-1-$ & $1 /-$ & $1 /-$ & $-/-$ \\
\hline Italy & $3 / 19(16)$ & $-/ 1$ & $-/-$ & $1 /-$ & $-/-$ & $-/ 1$ & $-/-$ & $-/-$ & $1 /-$ & $-/-$ & $-/-$ \\
\hline Portugal & $6 / 12(50)$ & $3 /-$ & $-/-$ & $1 /-$ & $-1-$ & $2 /-$ & $-/-$ & $-/-$ & $-1-$ & $-/-$ & $-/-$ \\
\hline Bulgaria & 4/9 (44) & $3 /-$ & $-/-$ & $-/-$ & $-/-$ & $-/-$ & $1 /-$ & $-/-$ & $-/-$ & $-/-$ & $-/-$ \\
\hline France & $0 / 9$ & $-1-$ & $-1-$ & $-/-$ & $-/-$ & $-1-$ & $-/-$ & $-1-$ & $-1-$ & $-/-$ & $-1-$ \\
\hline Croatia & 4/8 (50) & $2 /-$ & $-/-$ & $-/-$ & $-/-$ & $1 /-$ & $1 /-$ & $-/-$ & $-1-$ & $-/-$ & $-/-$ \\
\hline Turkey & 1/8 (13) & $1 /-$ & $-/-$ & $-1-$ & $-1-$ & $-1-$ & $-/-$ & $-/-$ & $-1-$ & $-1-$ & $-/-$ \\
\hline Cypress & $4 / 7(57)$ & $1 / 2$ & $-/-$ & $1 /-$ & $-/-$ & $-/ 1$ & $-/ 1$ & $-1-$ & $-1-$ & $-/-$ & $-/-$ \\
\hline Malta & $4 / 7(57)$ & $1 / 1$ & $-/-$ & $-/ 3$ & $-/-$ & $-/ 2$ & $-1-$ & $-1-$ & $-1-$ & $-/-$ & $-/-$ \\
\hline Romania & $1 / 7(14)$ & $1 /-$ & $-/-$ & $-/-$ & $-/-$ & $-/-$ & $-/-$ & $-/-$ & $-1-$ & $-/-$ & $-1-$ \\
\hline Slovenia & $0 / 3$ & $-1-$ & $-/-$ & $-/-$ & $-/-$ & $-/-$ & $-/-$ & $-/-$ & $-/-$ & $-/-$ & $-/-$ \\
\hline Israel & $1 / 1(100)$ & $1 /-$ & $-/-$ & $-1-$ & $-1-$ & $-1-$ & $-1-$ & $-1-$ & $-1-$ & $-/-$ & $-1-$ \\
\hline Montenegro & $1 / 1(100)$ & $-1-$ & $-/-$ & $1 /-$ & $-1-$ & $-1-$ & $-1-$ & $-1-$ & $-1-$ & $-/-$ & $-/-$ \\
\hline Tunisia & $0 / 1$ & $-1-$ & $-/-$ & $-/-$ & $-1-$ & $-/-$ & $-/-$ & $-/-$ & $-1-$ & $-/-$ & $-1-$ \\
\hline Total & $122 / 345$ & $31 / 15$ & $1 /-$ & $46 / 20$ & $1 /-$ & $8 / 16$ & $2 / 1$ & $0 / 1$ & $5 / 3$ & $1 / 2$ & $-/ 1$ \\
\hline
\end{tabular}

${ }^{a}$ Not differentiated Babesia spp. PCR (polymerase chain reaction)

${ }^{\mathrm{b}}$ Serological cross-reactions between $B$. canis and $B$. vogeli possible

'Non-differentiated Knott's test

Abbreviations: E. can, Ehrlichia canis; A. pla, Anaplasma platys; L. inf, Leishmania infantum; B. spp., Babesia spp.; B. can, Babesia canis; H. can, Hepatozoon canis; D. spp., Dirofilaria spp.; D. imm, Dirofilaria immitis; D. rep, Dirofilaria repens; Ac. rec, Acanthocheilonema reconditum

for multiple pathogens. Only dogs originating from the Mediterranean region had positive test results for more than one pathogen, especially E. canis and Babesia spp. Both pathogens can induce immunosuppression which can promote an infection with further pathogens [24, 25]. The prevalence of vector-borne infections is, amongst other biotic and abiotic factors, determined by the presence of competent vectors. $B$. vogeli, $E$. canis, $A$. platys and $H$. canis are reliant on Rhipicephalus sanguineus as a vector, which can transmit various individual pathogens and thus more than one infection [2]. As R. sanguineus can only temporarily survive as an outdoor tick in temperate regions including Germany and as an indoor population only in year-round tempered buildings [26], the exposure reported here can most likely be attributed to previous infections in the dogs' country of origin. Certain Dirofilaria species could develop natural transmission cycles in Germany and to date this has been proven for $D$. repens [27]. As D. immitis and A. reconditum are not endemic in Germany, infections with these parasites are most likely imported. Regarding the three dogs (from Spain, Hungary, Greece) that were infected with D. repens and presented between 2011 and 2014, an infection would have been possible in their home country as well as (though perhaps less likely) in the region Berlin-Brandenburg. Studies conducted in Brandenburg

Table 3 Number of dogs tested positive for vector-borne infections after time between import and presentation in the clinic

\begin{tabular}{lllllllll}
\hline Period & Positive/total (\%) & E. canis & A. platys & L. infantum & Babesia spp. & H. canis & Dirofilaria spp. & Multiple infections \\
\hline No data & $22 / 67(33)$ & 6 & - & 8 & 4 & 1 & 1 & 2 \\
0-2 months & $26 / 50(52)$ & 8 & 1 & 6 & 2 & 1 & 1 & 7 \\
2-6 months & $10 / 33(30)$ & 2 & - & 1 & 1 & - & 1 & 5 \\
6-12 months & $16 / 44(36)$ & 3 & - & 5 & 1 & - & 1 & 6 \\
1-5 years & $39 / 98(40)$ & 8 & - & 22 & 1 & - & -2 & 6 \\
5-7 years & $6 / 18(33)$ & 3 & - & 3 & - & - & - & 1 \\
$>7$ years & $3 / 35(9)$ & 1 & - & 1 & - & 2 & 6 & 27 \\
Total & $122 / 345(35)$ & 31 & 1 & 46 & 9 & &
\end{tabular}


Table 4 Number of positive tests for vector-borne infections in dogs imported to Germany

\begin{tabular}{llll}
\hline Infectious agent/test & No. of dogs tested positive/total (\%) & Direct tests (positive/total) & Indirect tests (positive/total) \\
\hline Ehrlichia canis & $45 / 278(16)$ & $8 / 68^{\mathrm{a}}$ & $43 / 257^{\mathrm{b}}$ \\
Anaplasma platys & $1 / 21(5)$ & $1 / 21^{\mathrm{a}}$ & - \\
Leishmania infantum & $66 / 314(21)$ & $20 / 79^{\mathrm{a}}$ & $57 / 276^{\mathrm{b}} ; 6 / 32^{\mathrm{c}}$ \\
Babesia spp. & $3 / 98(3)$ & $3 / 98^{\mathrm{a}, \mathrm{d}}$ & - \\
Babesia canis & $22 / 213(10)$ & - & $20 / 187^{\mathrm{b}} ; 2 / 27^{\mathrm{c}}$ \\
Babesia gibsoni & $0 / 13(0)$ & - & $0 / 13^{\mathrm{b}}$ \\
Hepatozoon canis & $3 / 28(11)$ & $3 / 28^{\mathrm{a}}$ & - \\
Babesia spp./Hepatozoon spp. & $0 / 8(0)$ & $0 / 8^{\mathrm{a}}$ & - \\
Dirofilaria immitis & $8 / 156(5)$ & $8 / 156^{\mathrm{f}}$ & - \\
Microfilariae & $5 / 23(22)$ & $5 / 23^{\mathrm{a}}$ & - \\
Modified Knott's test & $7 / 95(7)$ & $7 / 95$ & - \\
Total & $122 / 345(35)$ & $55 / 576(10 \%)$ & $128 / 792(16 \%)$ \\
\hline
\end{tabular}

Polymerase chain reaction

${ }^{\mathrm{b}}$ Immunofluorescence antibody test

${ }^{\mathrm{C}}$ Antibody enzyme-linked immunosorbant assay

${ }^{d} 2 / 3$ positive $P C R$-tests were differentiated as $B$. canis, $1 / 3$ was not differentiated

eSerological cross-reactions between $B$. canis und $B$. vogeli possible

${ }^{\mathrm{f}}$ Antigen enzyme-linked immunosorbant assay

showed that climatic conditions in this region do allow the development to the infectious L3 larva during limited periods and certain temperature frames [17, 28]. The pathogen was detected in a local mosquito population in Brandenburg in 2011 and 2012 [29].
In total, 25 dogs were infected with Babesia spp. in our study. Autochthonous infections with B. canis in certain regions within Germany, such as the Upper Rhine [10], Bavaria [9, 30], Lower Saxony [31], RhinelandPalatinate [12] and Brandenburg [13, 32], have been

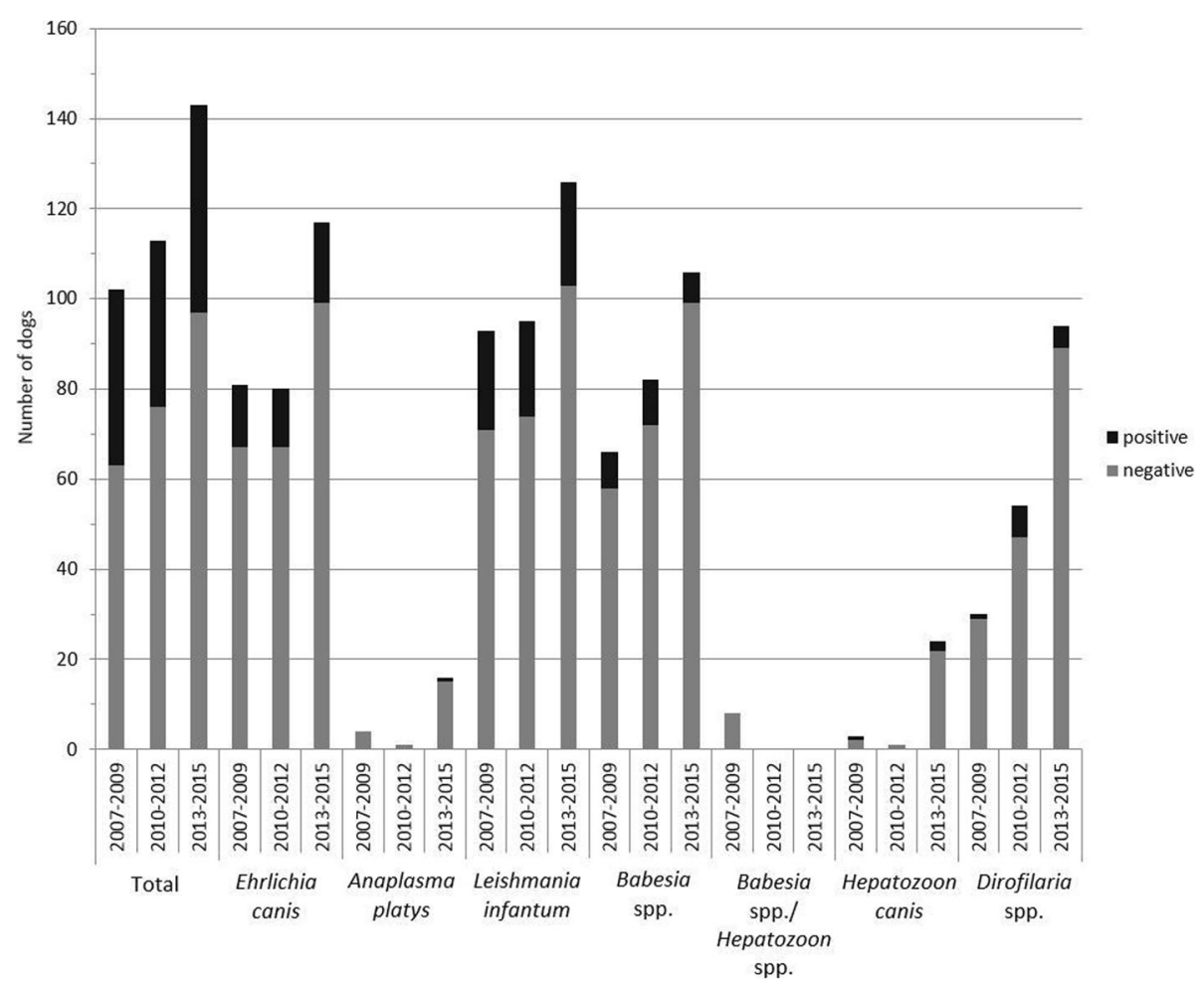

Fig. 1 Number of dogs tested for vector-borne infections between 2007 and 2015 
described. In a questionnaire-based survey with 313 Babesia-infected German dogs which had never left the home country, autochthonous infections have been found in dogs from Saarland (number of positive dogs $=225$ ), Baden-Württemberg $(n=20)$, Bavaria $(n=18)$, North Rhine-Westphalia $(n=18)$, Rhineland Palatinate $(n=6)$, Thuringia $(n=5)$, Saxony $(n=4)$, Saxony-Anhalt $(n=4)$, Hesse $(n=4)$, Lower Saxony $(n=3)$, Schleswig Holstein $(n=3)$, Berlin $(n=2)$ and Brandenburg $(n=1)$ [11]. Twenty-two of the 25 dogs in our study were only serologically positive for Babesia spp., with no differentiation between an infection with $B$. vogeli or $B$. canis. Twenty-one of 22 dogs originated from the Mediterranean area (mainly Spain and Greece), and one of the 22 dogs was originally from Hungary. Generally, B. canis occurs more often in central Europe, but it has also been found in the Mediterranean [33]. An infection with B. canis in Germany would be possible, but since most of the 22 serologically positive dogs did not show clinical signs of acute babesiosis $(n=18)$, were imported within one to seven weeks $(n=3)$ and/or were PCR-negative $(n=9)$, an infection within the country of origin seems more likely. Three of 25 Babesia-positive dogs had a positive PCR result. One dog with hemolytic anemia was from Hungary, but its PCR result was not further differentiated. This dog had only been in Germany for four weeks and was not serologically tested; an infection with B. canis in Hungary, which is an endemic region for this pathogen, was assumed. Two dogs were originally from Spain, and further differentiation of the PCR results revealed $B$. canis. These two dogs from Spain were presented due to hemolytic anemia and masticatory muscle myositis in 2010 and 2011, in which two studies did not detect B. canis in
Dermacentor reticulatus ticks from Berlin-Brandenburg $[34,35]$. Recently, in 2015, four dogs with B. canis infection were described, which were most likely infected in Berlin-Brandenburg [32]. Therefore, the infection of these two dogs from Spain could have occurred in Berlin-Brandenburg or in their country of origin. Ten of 22 dogs tested serologically positive for Babesia spp. had co-infections with L. infantum, which implies the possibility of serological cross-reactions between the two pathogens.

For B. gibsoni, vertical infections [36], as well as infections via bite wounds, saliva and blood contact [37-39], have to be considered as a transmission route, especially in non-endemic regions for specific vectors [40]. As $B$. gibsoni infections are usually of low importance and low prevalence in Germany, an infection occurring in the endemic country of the vector seems more likely for the dogs in our study.

Regarding $L$. infantum, individual cases of infections transmitted via mating [41, 42], transplacental [43-46] and bite wounds [47] have been described. It is most likely that these routes of infection do not play a part in our analysis.

In comparison to previous studies by Röhrig et al. [18] and Menn et al. [20], the amount of positive tested dogs was similar (Table 5). In addition to the Mediterranean area and southeastern Europe, regions such as northern Europe and Russia were considered as endemic regions in two studies $[18,20]$, respectively. However, some pathogens are not endemic in these regions, which could explain the lower prevalence of vector-borne infections in these studies. Furthermore, comparisons between the studies were difficult because of discrepancies regarding

Table 5 Prevalences of vector-borne infections in selected retrospective studies in imported dogs in Germany (positive results/ number of tested dogs)

\begin{tabular}{|c|c|c|c|}
\hline Infectious agent & Detection methods & Röhrig et al. [18] $]^{a}$ & Menn et al. [20] \\
\hline Period & & $2004-2008$ & 2004-2009 \\
\hline \multirow[t]{2}{*}{ Ehrlichia canis } & Direct & $5.3(3 / 57)$ & - \\
\hline & Indirect & $10.8(299 / 2763)$ & $10.1(492 / 4308)$ \\
\hline Hepatozoon canis & Direct & $1.1(26 / 2289)$ & $2.2(133 / 4548)$ \\
\hline \multirow[t]{2}{*}{ Anaplasma phagocytophilum } & Direct & $5.0(9 / 179)$ & - \\
\hline & Indirect & $29.8(130 / 436)$ & $22.4(332 / 1481)$ \\
\hline \multirow[t]{2}{*}{ Babesia canis } & Direct & $0.5(5 / 2289)$ & - \\
\hline & Indirect & $8.9(251 / 2819)$ & $24.3(1138 / 3507)$ \\
\hline \multirow[t]{2}{*}{ Leishmania infantum } & Direct & $14.9(14 / 94)$ & - \\
\hline & Indirect & $9.6(292 / 3049)$ & $12.2(569 / 3682)$ \\
\hline Dirofilaria immitis & Direct & $3(68 / 2223)$ & - \\
\hline Knott's test & Direct & $6.4(108 / 1685)$ & $7.7(372 / 4309)$ \\
\hline Prevalence & Positive dogs & $-(-/ 3531)$ & $43.7(2044 / 4681)$ \\
\hline
\end{tabular}

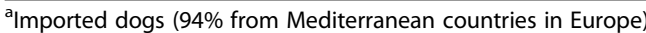

${ }^{\mathrm{b}}$ Proportion of dogs with holiday stays abroad $(n=87,1.8 \%)$ and number of dogs without anamnesis $(n=368,7.9 \%)$ 
the spectrum of vector-borne infections being analysed. The inclusion of $A$. phagocytophilum with high seroprevalence had an influence on the total prevalence of vector-borne infections $[18,20]$. Excluding the pathogen A. phagocytophilum from analyses, $L$. infantum, E. canis and B. canis were the most common infections (Table 5), which coincides with our results. The percentage of infections with Dirofilaria spp. was higher in our study (7\%) than in the study implemented by Röhrig et al. [18] (3\%).

As in our study, the above-mentioned studies did not test all pathogens via direct and indirect detection methods. In one of the studies $5.5 \%$ of direct and $20.5 \%$ of indirect testing methods were positive [18]. In all publications, the number of positive results tested via direct detection methods was considerably lower than those detected by indirect testing methods. In our study $10 \%$ of the direct test results and $16 \%$ of the indirect test results were positive. This implies that the infection was not acute in most dogs.

The number of multiple infections varied in the literature between 2.6\% [18] and 15\% [20]. Our results fall between these described prevalences. In the study by Menn et al. [20] import history was available in 4226 out of 4681 dogs (90.3\%). The remainder either accompanied their owners abroad or anamnestic information was non-existent. Dogs accompanying their owners on travels have a lower risk of vector-borne infections than imported dogs $[6,19,48,49]$. A prospective study examined dogs before starting their journey and at different time points after returning. A lower risk of infection for the individual dog was noticed for temporary visits in endemic countries [50].

For diagnostic purposes, it is important to differentiate between exposure to a pathogen, infection with a pathogen and clinical disease caused by an infection. Direct testing methods detect an antigen and might be positive if an infection is suspected to have occurred recently and no seroconversion has occurred yet [51]. PCR testing is also recommended in puppies, due to the existence of maternal antibodies [51]. In direct detection methods, an adequate amount of antigen has to be present in the bloodstream for a positive result, meaning that a negative result does not exclude the existence of an infection. A dog tested positive by direct testing methods can be classified as infected. Indirect testing methods detect antibodies against a pathogen. It is not possible to differentiate between exposure and infection with a single test. In the case of a four-fold rise or fall in titres, an infection is likely. On one hand indirect detection methods like IFAT and ELISA have a high sensitivity and specificity [52], but on the other hand limitations of serological examinations are cross-reactions, false-negative results in young or immunosuppressed dogs, and the premature implementation of tests post-infection before the beginning of seroconversion. In IFAT the subjective awareness, especially in borderline titre values, plays an important role and has effects on sensitivity and specificity [53]. Therefore, a combination of indirect and direct detection methods is recommended whilst taking the prepatency of the individual pathogen into account, especially in imported dogs with an unknown time of infection. Important information includes the dog's country of origin, the time of import to Germany, domestic and international travels and clinical signs. Following this, direct and/or indirect detection methods for the particular pathogen should be initiated. A differentiation between exposure/infection and clinical disease should be made on the basis of clinical and clinicopathological signs and by exclusion of differential diagnoses causing similar signs.

In Dirofilaria, the prepatency of six months must be considered. In 71 dogs of the study, which were presented within the first six months after import, there was the possibility of a false-negative result due to the premature initiation of tests. Microfilariae can survive in the bloodstream for two years, which means that dogs treated with adulticide medication or dogs with naturally eliminated infections are positive for microfilaria but negative when tested for antigens using ELISA during this time. This was the case for one dog of the study. In dogs treated prophylactically, the antigen release can be delayed for up to nine months post-infection [54]. A negative result for microfilariae with a positive proof of antigen, as seen in two dogs in the study, can occur for several reasons: the prepatency of six months post-infection, infection with same-sex worms, medicinal sterilisation of adult worms by use of macrolides and/or doxycycline, previous treatment against microfilariae or immune-mediated elimination of the circulating microfilaria in the blood [55]. Due to the necessity of detecting all Dirofilaria stages, an examination via an enrichment process for microfilariae (Knott's test) or microfilariae PCR combined with an antigen test is recommended. The sensitivity of PCR for the detection of $L$. infantum depends on the number of parasites in the examined medium [56]. In one study, sensitivities of $87 \%$ in blood and $100 \%$ in bone marrow are described [57]. Infected dogs often show low or borderline antibody titres because of the dominating TH1-immune response [58]. Seroconversion after natural infection may occur at different times according to literature: one to three months post-infection [59], 12 months post-infection [60] and up to 12-36 months post-infection [61]. The possibility of an absent seroconversion in infected dogs is also discussed [61]. Tests for Leishmania and Dirofilaria should be repeated after six months if the initial result is negative because of the long time for seroconversion of Leishmania and the long prepatency for Dirofilaria [51]. For these pathogens in particular, there is the possibility of a higher number of infections than stated in our study. 
Ehrlichia canis can be detected via PCR before the beginning of seroconversion, between days four and ten post-infection $[62,63]$ and via IFAT starting at day 14 post-infection (range one to four weeks) [62-64]. Due to the early seroconversion of this pathogen, the risk for false-negative results (unlike for Leishmania and Dirofilaria) on the grounds of premature initiation of tests is low. PCR is considered to be the most sensitive method of detection for A. platys [65]. Babesia canis can be detected in blood seven days post-infection via PCR [66]. Specific antibodies for B. canis were detected 14 days post-infection in experimentally infected dogs. Babesia canis, B. vogeli and B. rossi can cross-react in an IFAT or ELISA. On a species-level, Babesia spp. can also cause cross-reactions in an IFAT as well as in an antibody ELISA when whole antigen is used, for example between B. canis and B. gibsoni [33]. The serological detection of $H$. canis is not common in routine diagnosis and PCR is considered to be the best method of detection $[67,68]$. In our study, 28 dogs were tested for $H$. canis, with a greater number undergoing tests between 2013 and 2015. This shows that there is an increasing awareness for this vector-borne infection. Immunosuppressed, immunodeficient and co-infected dogs, in particular, suffer from $H$. canis [69]. In our study one third of $H$. canis positive tested dogs suffered from further infections.

This survey included examinations in clinically sick as well as asymptomatic dogs. The prevalence for vectorborne infections also depends on the health status of the tested dogs [70]. Prophylaxis is especially important for dogs accompanying their owners during travels. In a literature review, great regional differences in prevalence within various endemic countries were presented [70]. Regarding the risk of infection, there are not only differences between the countries, but also between the individual regions within a country. Our study retrospectively included the countries of origin, but not the different regions within these individual countries.

The evaluability of the results was limited due to the retrospective character of the study and the fact that not all tests were performed in all dogs. Reasons for this could be that owners were financially restricted, tests had already been initiated beforehand, or invalid test results. Additionally, the precision of diagnostic testing methods improved between 2007 and 2015. Nevertheless, the amount of 122/345 (35\%) imported dogs being tested positive for vector-borne infections is remarkable. Due to climatic changes, the increasing import of dogs from endemic regions, the increase of tourism within Europe and the spatial expansion of potential vectors, it is recommended to protect all dogs in Germany prophylactically from vector-borne infections independent of origin or region. Because of the zoonotic potential of some pathogens, the prophylaxis, treatment and screening of vector-borne infections in dogs are also of great importance for human medicine [2].

\section{Conclusions}

More than one third of dogs (35\%) were positive for at least one pathogen. Dogs, which are imported from countries which are endemic for vector-borne infections should be thoroughly tested using direct and indirect detection methods. Furthermore, a second examination should be considered in recently imported dogs and infections with a long prepatency or a long time until seroconversion (e.g. L. infantum and Dirofilaria spp. after six months). The owners of imported dogs should be informed extensively about the diseases and their risks.

\section{Abbreviations}

Ab: Antibody; Ag: Antigen; ELISA: Enzyme-linked immunosorbent assay; IFAT: Indirect immunofluorescence test; PCR: Polymerase chain reaction; TH1: T-helper-cells 1

\section{Acknowledgements}

The publication fee was sponsored by Bayer Animal Health.

Funding

Not applicable.

\section{Availability of data and materials}

All data generated or analysed during this study are included in this published article. Parts of this study were presented as a poster at the 28th Annual Meeting of the German Society for Parasitology in Berlin, Germany (21-24 March 2018) and as an oral presentation on the DVG-Congress in Berlin, Germany (4-7 October 2018).

\section{Authors' contributions}

IS collected and evaluated the data and wrote the manuscript. BK initiated and supervised the study and edited the manuscript. MV and RM supported the statistical analyses and edited the manuscript. EM and PB were responsible for laboratory analyses and edited the manuscript. All authors read and approved the final manuscript.

Ethics approval and consent to participate

Not applicable.

Consent for publication

Not applicable.

Competing interests

The authors declare that they have no competing interests.

\section{Publisher's Note}

Springer Nature remains neutral with regard to jurisdictional claims in published maps and institutional affiliations.

\section{Author details}

${ }^{1}$ Clinic for Small Animals, Faculty of Veterinary Medicine, Freie Universität Berlin, Berlin, Germany. ${ }^{2}$ Institute of Veterinary Epidemiology and Biostatistics, Freie Universität Berlin, Berlin, Germany. ${ }^{3}$ Chair for Experimental Parasitology, Faculty of Veterinary Medicine, Ludwig-Maximilians-Universität Munich, Munich, Germany. ${ }^{4}$ Laboklin GmbH and Co.KG, Bad Kissingen, Germany.

Received: 7 September 2018 Accepted: 28 December 2018 Published online: 11 January 2019

\section{References}

1. Baneth G, Bourdeau P, Bourdoiseau G, Bowman D, Breitschwerdt E, Capelli $\mathrm{G}$, et al. Vector-borne diseases - constant challenge for practicing 
veterinarians: recommendations from the CVBD World Forum. Parasit Vectors. 2012;5:55.

2. ESCCAP. Control of Vector-Borne Diseases in Dogs and Cats. Malvern, UK: European Scientific Counsel Companion Animal Parasites; 2012.

3. Cortese L, Terrazzano G, Piantedosi D, Sica M, Prisco M, Ruggiero G, Ciaramella P. Prevalence of anti-platelet antibodies in dogs naturally coinfected by Leishmania infantum and Ehrlichia canis. Vet J. 2011;188:118-21.

4. Mekuzas Y, Gradoni L, Oliva G, Foglia Manzillo V, Baneth G. Ehrlichia canis and Leishmania infantum co-infection: a 3-year longitudinal study in naturally exposed dogs. Clin Microbiol Infect. 2009;15(Suppl. 2):30-1.

5. Shaw SE, Day MJ, Birtles RJ, Breitschwerdt EB. Tick-borne infectious diseases of dogs. Trends Parasitol. 2001;17:74-80.

6. Glaser B, Gothe R. Dog tourism and import: an inquiry in Germany on the extent as well as on the spectrum and preference of countries of residence and origin respectively. Tieraerztl Prax KH. 1998;26:197-202 (In German).

7. Hartelt K, Oehme R, Frank H, Brockmann SO, Hassler D, Kimmig P. Pathogens and symbionts in ticks: prevalence of Anaplasma phagocytophilum (Ehrlichia sp.), Wolbachia sp., Rickettsia sp., and Babesia sp. in southern Germany. Int J Med Microbiol. 2004;293(Suppl. 37):86-92.

8. Jensen J, Nolte I. Autochthone infection with Babesia canis in a dog from northern Germany. Tieraerztl Prax KH. 2005;33:408-12 (In German).

9. Zahler M, Steffen T, Lutz S, Hahnel WC, Rinder H, Gothe R. Babesia canis and Dermacentor reticulatus in Munich: a new endemic focus in Germany. Tierarztl Prax KH. 2000:28:116-20 (In German).

10. Gothe R, Wegerdt S. Babesiosis of dogs in Germany: epidemiologic case analysis. Tierarztl Prax KH. 1991;19:170-3 (In German).

11. Barutzki D, Reule M, Scheunemann R, Heile C, Schein E. Die Babesiose des Hundes - eine autochtone Erkrankung in Deutschland. Deutsches Tierärzteblatt. 2007:3:284-93.

12. Kehl A, Hübner J, Müller E. Ein endemischer Fall von Babesiose des Hundes. Kleintiermedizin. 2005;9:258-61.

13. Heile C, Heydorn AO, Schein E. Dermacentor reticulatus (Fabricius, 1794) distribution, biology and vector for Babesia canis in Germany. Berl Munch Tierarztl Wochenschr. 2006;119:330-4 (In German).

14. Hartelt K, Rieker T, Oehme RM, Brockmann SO, Muller W, Dorn N. First evidence of Babesia gibsoni (Asian genotype) in dogs in Western Europe. Vector Borne Zoonotic Dis. 2007:7:163-6.

15. Hermosilla C, Pantchev N, Dyachenko V, Gutmann M, Bauer C. First autochthonous case of canine ocular Dirofilaria repens infection in Germany. Vet Rec. 2006;158:134-5.

16. Pantchev N, Norden N, Lorentzen L, Rossi M, Rossi U, Brand B, Dyachenko V. Current surveys on the prevalence and distribution of Dirofilaria spp. in dogs in Germany. Parasitol Res. 2009;105(Suppl. 1):63-74.

17. Sassnau R, Kohn M, Demeler J, Kohn B, Müller E, Krücken J. von SamsonHimmelstjerna G. Is Dirofilaria repens endemic in the Havelland district in Brandenburg, Germany? Vector Borne Zoonotic Dis. 2013;13:888-91.

18. Röhrig $E$, Hamel $D$, Pfister K. Retrospective evaluation of laboratory data on canine vector-borne infections from the years 2004-2008. Berl Munch Tierarztl Wochenschr. 2011;124:411-8 (In German).

19. Hirsch M, Pantchev N. Occurrence of the travel diseases leishmaniosis, ehrlichiosis, babesiosis and dirofilariosis in dogs living in Germany. Kleintierpraxis. 2008:53:154-65 (In German).

20. Menn B, Lorentz S, Naucke TJ. Imported and travelling dogs as carriers of canine vector-borne pathogens in Germany. Parasit Vectors. 2010;3:34.

21. Glaser B, Gothe R. Imported arthropod-borne parasites and parasitic arthropods in dogs. Species spectrum and epidemiologic analysis of the cases diagnosed in 1995/96. Tierarztl Prax KH. 1998;26:40-6 (In German).

22. Vrhovec MG, Pantchev N, Failing K, Bauer C, Travers-Martin N, Zahner H. Retrospective analysis of canine vector-borne diseases (CVBD) in Germany with emphasis on the endemicity and risk factors of leishmaniosis. Parasitol Res. 2017;116(Suppl. 1):131-44.

23. Csokai J, Klas EM, Heusinger A, Müller E. Occurrence of Ehrlichia canis in dogs living in Germany and comparison of direct and indirect diagnostic methods. Tierarztl Prax KH. 2017:45:301-7 (In German).

24. Adachi K, Ueno C, Makimura S. Immunosuppression in dogs naturally infected with Babesia gibsoni. J Vet Med Sci. 1993;55:503-5.

25. Nyindo M, Huxsoll DL, Ristic M, Kakoma I, Brown JL, Carson CA, Stephenson EH. Cell-mediated and humoral immune responses of German Shepherd Dogs and Beagles to experimental infection with Ehrlichia canis. Am J Vet Res. 1980;41:250-4.
26. Pantchev N, Pluta S, Huisinga E, Nather S, Scheufelen M, Vrhovec MG, et al. Tick-borne diseases (borreliosis, anaplasmosis, babesiosis) in German and Austrian dogs: Status quo and review of distribution, transmission, clinical findings, diagnostics and prophylaxis. Parasitol Res. 2015;114(Suppl. 1):S19-54.

27. Kronefeld M, Kampen H, Sassnau R, Werner D. Molecular detection of Dirofilaria immitis, Dirofilaria repens and Setaria tundra in mosquitoes from Germany. Parasit Vectors. 2014;7:30.

28. Sassnau R, Dyachenko V, Pantchev N, Stockel F, Dittmar K, Daugschies A Dirofilaria repens infestation in a sled dog kennel in the federal state of Brandenburg (Germany). Diagnosis and therapy of canine cutaneous dirofilariosis. Tieraerztl Prax KH. 2009;37:95-101 (In German).

29. Czajka C, Becker N, Jost H, Poppert S, Schmidt-Chanasit J, Kruger A, Tannich E. Stable transmission of Dirofilaria repens nematodes, northern Germany. Emerg Infect Dis. 2014;20:328-31.

30. Zahler M, Loster F, Merkle C, Rinder H. Infektionsgefahr für Hunde in Regensburg - ein neuer Naturherd von Babesia canis und Dermacentor reticulatus in Deutschland. Tieraerztl Prax KH. 2000b;28:395-8.

31. Jensen J, Simon D, Schaarschmidt-Kiener D, Müller W, Nolte I. Prevalence of Ehrlichia canis in Germany. Tierarztl Prax KH. 2007;35:123-8 (In German).

32. Weingart C, Krücken J, Rueter M-T, Von Samson-Himmelstjerna G, Kohn B. Canine Babesiose - vier autochthone Fälle in Norddeutschland (2017). Tieraerztl Prax KH. 2017;45:A16-A17 (In German).

33. Solano-Gallego L, Sainz A, Roura X, Estrada-Pena A, Miro G. A review of canine babesiosis: the European perspective. Parasit Vectors. 2016;9:336.

34. Schreiber C, Krücken J, Beck S, Maaz D, Pachnicke S, Krieger K, et al. Pathogens in ticks collected from dogs in Berlin/Brandenburg, Germany. Parasit Vectors. 2014;7:535.

35. Kohn M, Krucken J, McKay-Demeler J, Pachnicke S, Krieger K, von SamsonHimmelstjerna G. Dermacentor reticulatus in Berlin/Brandenburg (Germany): Activity patterns and associated pathogens. Ticks Tick Borne Dis. 2018. https://doi.org/10.1016/.ttbdis.2018.10.003.

36. Fukumoto S, Suzuki H, Igarashi I, Xuan X. Fatal experimental transplacental Babesia gibsoni infections in dogs. Int J Parasitol. 2005;35:1031-5.

37. Jefferies R, Ryan UM, Jardine J, Broughton DK, Robertson ID, Irwin PJ. Blood, Bull Terriers and babesiosis: further evidence for direct transmission of Babesia gibsoni in dogs. Aust Vet J. 2007:85:459-63.

38. Yeagley TJ, Reichard MV, Hempstead JE, Allen KE, Parsons LM, White MA, et al. Detection of Babesia gibsoni and the canine small Babesia 'Spanish isolate' in blood samples obtained from dogs confiscated from dogfighting operations. J Am Vet Med Assoc. 2009;235:535-9.

39. Birkenheuer AJ, Correa MT, Levy MG, Breitschwerdt EB. Geographic distribution of babesiosis among dogs in the United States and association with dog bites: 150 cases (2000-2003). J Am Vet Med Assoc. 2005;227:942-7.

40. Birkenheuer AJ. Babesiosis. In: Greene $C E$, editor. Infectious Diseases of the Dog and Cat. 4th ed. Oxford: Elsevier; 2012. p. 771-884.

41. Benites AP, Fernandes CE, Brum KB, Abdo MAGS. Presence of amastigotes forms the Leishmania chagasi and profile the leucocytes cells in the reproductive tract of dogs. Pesquisa Vet Brasil. 2011;31:72-7.

42. Turchetti AP, Souza TD, Paixao TA, Santos RL. Sexual and vertical transmission of visceral leishmaniasis. J Infect Dev Ctries. 2014;8:403-7.

43. Gibson-Corley KN, Hostetter JM, Hostetter SJ, Mullin K, Ramer-Tait AE, Boggiatto PM, Petersen CA. Disseminated Leishmania infantum infection in two sibling foxhounds due to possible vertical transmission. Can Vet J. 2008:49:1005-8.

44. Petersen CA. Leishmaniasis, an emerging disease found in companion animals in the United States. Top Companion Anim Med. 2009;24:182-8.

45. Boggiatto PM, Gibson-Corley KN, Metz K, Gallup JM, Hostetter JM, Mullin K, Petersen CA. Transplacental transmission of Leishmania infantum as a means for continued disease incidence in North America. PLoS Negl Trop Dis. 2011;5:e1019.

46. Ben Slimane T, Chouihi E, Ben Hadj Ahmed S, Chelbi I, Barhoumi W, Cherni $\mathrm{S}$, et al. An investigation on vertical transmission of Leishmania infantum in experimentally infected dogs and assessment of offspring's infectiousness potential by xenodiagnosis. Vet Parasitol. 2014;206:282-6.

47. Naucke TJ, Amelung S, Lorentz S. First report of transmission of canine leishmaniosis through bite wounds from a naturally infected dog in Germany. Parasit Vectors. 2016;9:256.

48. Hamel D, Rohrig E, Pfister K. Canine vector-borne disease in travelled dogs in Germany - a retrospective evaluation of laboratory data from the years 2004-2008. Vet Parasitol. 2011;181:31-6.

49. Schäfer I, Volkmann M, Beelitz P, Müller E, Merle R, Kohn B. Retrospective analysis of vector-borne infections in dogs after travelling to endemic areas (2007-2015). Kleintierprax. 2018;63:551-2 (In German). 
50. Hamel D, Silaghi C, Pfister K. Arthropod-borne infections in travelled dogs in Europe. Parasite. 2013;20:9

51. Pantchev N, Nather S, Globokar M. Reisekrankheiten und deren Nachweisverfahren. Kompendium Kleintier. 2017:18-22 (In German).

52. Solano-Gallego L, Villanueva-Saz S, Carbonell M, Trotta M, Furlanello T, Natale A. Serological diagnosis of canine leishmaniosis: comparison of three commercial ELISA tests (Leiscan ${ }^{\oplus}$, ID Screen ${ }^{\oplus}$ and Leishmania $96^{\circledR}$ ), a rapid test (Speed Leish $\mathrm{K}^{\circledast}$ ) and an in-house IFAT. Parasit Vectors. 2014;7:111.

53. Mettler M, Grimm F, Naucke TJ, Maasjost C, Deplazes P. Canine leishmaniosis in central Europe: retrospective survey and serological study of imported and travelling dogs. Berl Munch Tierarztl Wochenschr. 2005;118: 37-44 (In German).

54. Nelson TC. Canine heartworm disease. In: Greene CE. Infectious Diseases of the Dog and Cat. 4th ed. Oxford: Elsevier; 2012. p. 865-73.

55. Borthakur SK, Deka DK, Islam S, Sarmah PC. Occult dirofilariosis in dogs of north eastern region in India. J Arthropod Borne Dis. 2016;10:92-7.

56. Hernandez L, Montoya A, Checa R, Dado D, Galvez R, Otranto D, et al. Course of experimental infection of canine leishmaniosis: follow-up and utility of noninvasive diagnostic techniques. Vet Parasitol. 2015;207:149-55.

57. Steuber S, Moritz A, Schirrmann I. Greiner M. PCR follow-up examination after treatment of canine leishmaniosis (CaL). Tokai J Exp Clin Med. 1998;23:285-92.

58. Boggiatto PM, Ramer-Tait AE, Metz K, Kramer EE, Gibson-Corley K, Mullin K, et al. Immunologic indicators of clinical progression during canine Leishmania infantum infection. Clin Vaccine Immunol. 2010;17:267-73.

59. Moreno J, Alvar J. Canine leishmaniasis: epidemiological risk and the experimental model. Trends Parasitol. 2002;18:399-405.

60. Naucke TJ, Lorentz S. Non-sandfly transmission of canine leishmaniasis. Tieraerztl Umschau. 2013;68:121-5 (In German).

61. Solano-Gallego L, Llull J, Ramis A, Fernandez-Bellon H, Rodriguez A, Ferrer $L$, Alberola J. Longitudinal study of dogs living in an area of Spain highly endemic for leishmaniasis by serologic analysis and the leishmanin skin test. Am J Trop Med Hyg. 2005;72:815-8.

62. Harrus S, Kenny M, Miara L, Aizenberg I, Waner T, Shaw S. Comparison of simultaneous splenic sample PCR with blood sample PCR for diagnosis and treatment of experimental Ehrlichia canis infection. Antimicrob Agents Chemother. 2004;48:4488-90.

63. Wen B, Rikihisa Y, Mott JM, Greene R, Kim HY, Zhi N, et al. Comparison of nested PCR with immunofluorescent-antibody assay for detection of Ehrlichia canis infection in dogs treated with doxycycline. J Clin Microbiol. 1997;35:1852-5

64. McBride JW, Corstvet RE, Gaunt SD, Chinsangaram J, Akita GY, Osburn BI. PCR detection of acute Ehrlichia canis infection in dogs. J Vet Diagn Invest. 1996:8:441-7.

65. Harvey JW. Anaplasma platys infection (thrombocytotropic anaplasmosis). In: Greene CE. Infectious Diseases of the Dog and Cat. 4th ed. Oxford: Elsevier; 2012. p. 256-8.

66. Deplazes P, Staebler S, Gottstein B. Travel medicine of parasitic diseases in the dog. Schweiz Arch Tierheilkd. 2006;148:447-61 (In German).

67. Otranto D, Dantas-Torres F, Weigl S, Latrofa MS, Stanneck D, Decaprariis D, et al. Diagnosis of Hepatozoon canis in young dogs by cytology and PCR. Parasit Vectors. 2011:4:55.

68. Vojta L, Mrljak V, Curkovic S, Zivicnjak T, Marinculic A, Beck R. Molecular epizootiology of canine hepatozoonosis in Croatia. Int J Parasitol. 2009; 39:1129-36.

69. Baneth G. Hepatozoon canis infection. In: Greene CE. Infectious Diseases of the Dog and Cat. 4th ed. Oxford: Elsevier; 2012. p. 750-7.

70. Trotz-Williams LA, Trees AJ. Systematic review of the distribution of the major vector-borne parasitic infections in dogs and cats in Europe. Vet Rec. 2003;152:97-105.

71. Messerer S. Entwicklung und Evaluierung von Real-time PCR-Verfahren zum Nachweis von Ehrlichia canis und Anaplasma phagocytophilum (Anaplasmataceae). Munich: LMU Munich; 2006.

72. Teglas M, Matern E, Lein S, Foley P, Mahan SM, Foley J. Ticks and tick-borne disease in Guatemalan cattle and horses. Vet Parasitol. 2005;131:119-27.

73. Mary C, Faraut F, Lascombe L, Dumon H. Quantification of Leishmania infantum DNA by a real-time PCR assay with high sensitivity. J Clin Microbiol. 2004;42:5249-55.

74. Francino O, Altet L, Sanchez-Robert E, Rodriguez A, Solano-Gallego L, Alberola J, et al. Advantages of real-time PCR assay for diagnosis and monitoring of canine leishmaniosis. Vet Parasitol. 2006;137:214-21.
75. Mancianti F, Falcone ML, Giannelli C, Poli A. Comparison between an enzyme-linked immunosorbent assay using a detergent-soluble Leishmania infantum antigen and indirect immunofluorescence for the diagnosis of canine leishmaniosis. Vet Parasitol. 1995;59:13-21.

76. Casati S, Sager H, Gern L, Piffaretti JC. Presence of potentially pathogenic Babesia sp. for human in Ixodes ricinus in Switzerland. Ann Agric Environ Med. 2006;13:65-70.

77. Zahler M, Schein E, Rinder H, Gothe R. Characteristic genotypes discriminate between Babesia canis isolates of differing vector specificity and pathogenicity to dogs. Parasitol Res. 1998;84:544-8.

78. Inokuma H, Okuda M, Ohno K, Shimoda K, Onishi T. Analysis of the $18 \mathrm{~S}$ rRNA gene sequence of a Hepatozoon detected in two Japanese dogs. Vet Parasitol. 2002;106:265-71.

79. Rommel M, Kutzer E, Körting W, Schnieder T. Veterinärmedizinische Parasitologie, vol. 5. Berlin: Parey Verlag; 2000.

80. Rishniw M, Barr SC, Simpson KW, Frongillo MF, Franz M, Dominguez Alpizar $J$ L. Discrimination between six species of canine microfilariae by a single polymerase chain reaction. Vet Parasitol. 2006;135:303-14.
Ready to submit your research? Choose BMC and benefit from:

- fast, convenient online submission

- thorough peer review by experienced researchers in your field

- rapid publication on acceptance

- support for research data, including large and complex data types

- gold Open Access which fosters wider collaboration and increased citations

- maximum visibility for your research: over $100 \mathrm{M}$ website views per year

At BMC, research is always in progress.

Learn more biomedcentral.com/submissions 